\title{
Michał Polak
}

\section{Obchody rocznic narodowych przez polskie uchodźstwo polityczne w Wielkiej Brytanii w świetle wydawnictw okolicznościowych Juliusza Ludwika Englerta}

\begin{abstract}
Abstrakt: Niniejszy artykuł zawiera prezentację wyników badań nad pracami Juliusza L. Englerta jako kronikarza emigracji, grafika i współautora programów obchodów rocznic narodowych. Podstawę źródłową tych rozważań stanowi szeroki dorobek publikacyjny Englerta, dostępny głównie w archiwach i bibliotekach polskich w Wielkiej Brytanii. Prace kronikarza są doskonałym materiałem poglądowym na temat genezy, okoliczności i przebiegu obchodów ważnych dla polskiego uchodźstwa wydarzeń z historii Polski.
\end{abstract}

Słowa kluczowe: Juliusz L. Englert, obchody rocznic narodowych, uchodźstwo polskie w Wielkiej Brytanii, Józef Piłsudski, Władysław Sikorski.

Abstract: This article is a presentation of the results of research on the works of Juliusz L. Englert as a chronicler of the emigration, graphic artist and co-author of the programmes celebrating national historical anniversaries. The study is based on Englert's extensive publishing output, available mainly in Polish archives and libraries in Great Britain. Englert's works are excellent demonstrative material for a thorough analysis of the genesis, circumstances and course of the celebrations of events from Polish history important for the Polish people in exile.

Keywords: Juliusz L. Englert, celebrations of national anniversaries, Polish refugees in Great Britain, Józef Piłsudski, Władysław Sikorski. 
Rząd Rzeczypospolitej na uchodźstwie w okresie od lipca 1945 r. do 1990 r. z sukcesem zrealizował misję zachowania ciagłości prawowitych władz polskich, stanowiąc symbol nieugiętej woli narodu do zachowania suwerenności od sił zewnętrznych. Polacy, którzy w dramatycznych okolicznościach podjęli decyzję o pozostaniu na obczyźnie, utworzyli społeczność na uchodźstwie, która jednoczyły polski język i tradycje, ale również pamięć o ważnych i symbolicznych wydarzeniach $\mathrm{z}$ historii Polski. Kultywowanie rocznic narodowych integrowało Polonię wokół sprawy polskiej, a także - co nie mniej istotne - służyło nagłaśnianiu postulatów uchodźstwa polskiego na arenie międzynarodowej wolnego świata.

Godne obchodzenie rocznic i jubileuszy było możliwe nie tylko dzięki zaangażowaniu władz polskich na obczyźnie, ale również wydatnemu włączeniu się społeczności polskiej na czele z wybitnymi społecznikami, którzy nie szczędzili talentów, sił i środków dla upamiętnienia ważnych w odczuciu Polaków wydarzeń z historii Polski.

Nie ulega wątpliwości, że mjr Juliusz Englert ${ }^{1}$ należał właśnie do takich społeczników. Był jedna z najbardziej rozpoznawalnych postaci w „polskim” Londynie przez kilkadziesiąt lat drugiej połowy minionego wieku i pierwszej dekady XXI w. Mnogość jego zainteresowań, a zwłaszcza pasja kronikarska przyniosły mu ogromne uznanie środowiska nie tylko uchodźczego, ale po 1989 r. także w Kraju. Znali go i cenili historycy, archiwiści, bibliotekarze, muzealnicy, szeroko rozumiane środowisko kombatanckie, ludzie kultury i polityki. Cieszył się uznaniem prezydentów RP na uchodźstwie, a od $1990 \mathrm{r}$. prezydentów niepodległej Polski.

Celem niniejszego artykułu jest przedstawienie wyników analizy prac Juliusza L. Englerta jako kronikarza emigracji, grafika i współautora programów obchodów rocznic narodowych. Podstawę źródłową tych rozważań stanowi szeroki dorobek publikacyjny Englerta, dostępny niestety głównie w archiwach i bibliotekach polskich w Wielkiej Brytanii, jak również znajdujacy się w moich zbiorach.

Na głęboki patriotyzm Englerta oraz nieustanna - do ostatnich chwil życia - służbę ojczyźnie oddziaływała atmosfera panująca w środowisku rodzinnym. Ogromny wpływ na kształtowanie osobowości Englerta wywarli rodzice: matka Wanda Barbara ${ }^{2}$ - członek Polskiej Organizacji Wojskowej (POW) i ojciec Adam Wincenty - legionista i historyk ${ }^{3}$.

\footnotetext{
${ }^{1}$ Szczegółowo na temat J.L. Englerta zob. Ojczyzna w obiektywie. Imponderabilia kronikarza Juliusza L. Englerta na emigracji, red. A. Biernat, W. Stępniak, Warszawa 2010; zob. też: L. Bednarek, W. Mrugała, Juliusz Ludwik Englert - żolnierz, fotograf, filatelista - historia o wyjatkowym człowieku, w: Katalog Krajowej Wystawy Filatelistycznej „Żotnierz polski podczas II wojny światowej”, red. T. Galant, Koszalin 2015, s. 65-72.

${ }^{2}$ Urodziła się 13 VI 1892 r. w Warszawie. Pochodziła z zamożnej rodziny. Jej ojciec Leon Rodwand był bankowcem. Zawarła związek małżeński z Adamem Wincentym Englertem, późniejszym podpułkownikiem i historykiem. W czasie II wojny światowej była żołnierzem
} 
Englert urodził się w Warszawie w 1927 r. Był żołnierzem Szarych Szeregów batalionu „Wigry”, ps. Adam, Jastrzębiec. Uczestniczył w Powstaniu Warszawskim na Woli, a od czerwca 1946 r. służył w 2 Korpusie dowodzonym przez gen. Władysława Andersa we Włoszech.

Po przyjeździe do Londynu ukończył studia w Borough Polytechnic. Nie zaprzestał działalności harcerskiej, organizując i obejmując kierownictwo 12 Kręgu Starszoharcerskiego im. prezydenta Warszawy Stefana Starzyńskiegó. Niezwykle aktywny, zają się działalnością patriotyczną oraz zaangażował się w działalność na rzecz Instytutu Polskiego i Muzeum im. gen. Sikorskiego, a także Instytutu Józefa Piłsudskiego oraz szeregu innych instytucji uchodźczych.

Spośród wielu jego zainteresowań i pasji należy wymienić fotografię zarówno portretowa, jak i kronikarska, grafikę, publicystykę i felietonistykę. Był twórca i organizatorem ponad 100 wystaw fotograficznych w kraju i w Wielkiej Brytanii. Wśród wielu różnych rysów biograficznych o jego osobie dominuje określenie - kronikarz emigracji - które najtrafniej oddaje ducha działalności Englerta. Był także autorem wielu projektów graficznych, programów i afiszów teatralnych, druków filatelistycznych oraz wydawnictw okolicznościowych ${ }^{5}$.

Englert zmarł 13 I 2010 r. po długiej chorobie. Pozostawił po sobie niezwykle bogatą spuściznę dokumentująca życie uchodźstwa, ale również publikacje popularnonaukowe propagujace historię Polski oraz przyjaźń polsko-brytyjską wśród Polaków i Brytyjczyków.

AK, ps. Zofia Wysocka; po upadku Powstania Warszawskiego w niewoli niemieckiej. W 1945 r. po uwolnieniu z obozu przez wojska alianckie pozostała na uchodźstwie w Wielkiej Brytanii. W latach pięćdziesiątych przeniosła się do Stanów Zjednoczonych. Po wojnie pracowała jako siostra szpitalna i pielęgniarka. Zmarła 6 X 1962 r. w River Forest w Stanach Zjednoczonych. Została odznaczona m.in. Krzyżem Niepodległości, Srebrnym Krzyżem Zasługi z Mieczami. Podaję za: J.K. Danel, Druga Wielka Emigracja 1945-1990. Stownik biograficzny, t. I, Zamość 2011, s. 593-594. Karolina Grodziska ustaliła (Polskie groby na cmentarzach Londynu, Kraków 1995, s. 150), że Wanda Englertowa, podobnie jak Adam Englert, pochowana została na londyńskim St. Mary's Roman Catholic Cemetery.

${ }^{3}$ Urodził się 11 XI 1890 r. w Stepaniu. Był absolwentem Uniwersytetu Warszawskiego. Działacz niepodległościowy i żołnierz I Brygady Legionów, członek POW i ppłk żandarmerii Wojska Polskiego. W Polsce niepodległej był współtwórca i dyrektorem Archiwum Miasta Stołecznego Warszawy. W okresie międzywojennym publikował m.in. w „Strzelcu”, „Bellonie”, „Przeglądzie Historyczno-Wojskowym”. Po wybuchu II wojny światowej przeszedł do konspiracji, jako członek SZP, ZWZ i AK. Został aresztowany przez gestapo po akcji pod Arsenałem i wywieziony do obozu koncentracyjnego w Oświęcimiu. Po wojnie udał się do Wielkiej Brytanii, gdzie zmarł 4 X 1958 r. w Londynie. Został odznaczony m.in. Krzyżem Niepodległości (pięciokrotnie), Krzyżem Walecznych i Złotym Krzyżem Zasługi. Podaję za: J.K. Danel, op. cit., s. 592-593; zob. też: A. Suchcitz, Pptk Adam Englert, w: Ojczyzna w obiektywie..., s. 19-21; K. Grodziska, op. cit., s. 150.

${ }^{4}$ W. Rostocki, „Stepań” w Londynie, w: Ojczyzna w obiektywie..., s. 15.

${ }^{5}$ M. Polak, Juliusza Englerta pamięć o Marszałku, w: Marszałek Józef Piłsudski w pamięci Polaków, red. nauk. P. Michalak, B. Polak, M. Polak, W. Wierzejewski, Koszalin 2016, s. 170. 


\section{Upamiętnienie czynu i życia marszałka Józefa Piłsudskiego oraz rocznic odzyskania niepodległości}

Dla Englerta niepodległościowa droga jego rodziców stała się źródłem wielu jego dokonań zmierzajacych do upamiętnienia w przeróżnych formach czynu Józefa Piłsudskiego i Legionów Polskich ${ }^{6}$. W związku z tym obchodzono na uchodźstwie najczęściej urodziny i imieniny, ale również rocznice śmierci Marszałka. Okazją do jego upamiętnienia były przede wszystkim rocznice odzyskania niepodległości.

W 50. rocznicę śmierci Komendanta mjr Englert wraz z Instytutem Józefa Piłsudskiego (IJP) w Londynie i Galerią Artystyczną Polskiego Ośrodka Społeczno-Kulturalnego (POSK) zorganizował w Londynie, w dniach od 1 do 12 V 1985 r., wystawę „Józef Piłsudski i Jego żołnierze. Wystawa w ramach obchodów 50 rocznicy zgonu Marszałka Polski”.

Ważnym nurtem twórczości Englerta są różnorodne projekty i opracowania graficzne. Pierwszy projekt - okładki - Englert wykonał w 1954 r. do publikacji $W$ czterdziestolecie wymarszu Legionów. Zbiór wspomnień, wydanej przez IJP. W 1967 r. zaangażował się w przygotowanie i oprawę graficzna Programu obchodów uczczenia setnej rocznicy urodzin Józefa Pitsudskiego. Jednym z wydarzeń tego roku była akademia „Setna rocznica urodzin Józefa Piłsudskiego. Żywa Legenda - droga życia J. Piłsudskiego w poezji i w pieśni”, która odbyła się 3 XII 1967 r. w Royal Albert Hall w Londynie 7 .

W 1979 r. Englert przygotował z kolei program uroczystości z okazji obchodów imienin Marszałka, mających miejsce w Ognisku Polskim w Londynie 17 marca $^{8}$. W 1982 r. ponownie zaangażował się w opracowanie programu uroczystości związanych z imieninami Piłsudskiego (19 marca). Uroczystość została zorganizowana przez IJP, a opiekę artystyczną zapewniła Maryna Buchwaldowa. Wystapił m.in. chór Młody Głos pod batuta Jacka Rumuna. Słowo wstępne wygłosił prezes Instytutu ppłk Janusz Rowiński, a uroczystość odbyła się w POSK. Englert przygotował program oraz współpracował

\footnotetext{
${ }^{6}$ Warto wspomnieć o ważnej publikacji popularnonaukowej na temat Piłsudskiego - albumie: Józef Pitsudski: Komendant - Naczelnik Państwa, Pierwszy Marszałek Polski, opracowanym wraz z Grzegorzem Nowikiem. Układ graficzny był autorstwa Englerta. Pierwsze wydanie ukazało się w Londynie w 1991 r. nakładem Polskiej Fundacji Kulturalnej i Editions Spotkania; wyd. 2 w 1996 r., a w 2007 r. ukazało się poprawione i uzupełnione wyd. 3, tym razem w Warszawie w Oficynie Wydawniczej Rytm. Album ten zasłużenie okazał się wielkim sukcesem wydawniczym, będąc do dziś najważniejszą popularnonaukowa publikacją albumową o polskim bohaterze. Szerzej na temat tej publikacji zob. M. Polak, op. cit., s. $172-173$.

${ }^{7}$ Ibidem, s. 173. Program obchodów uczczenia setnej rocznicy urodzin Józefa Piłsudskiego, opracowanie graficzne J.L. Englert, Londyn 3 XII 1967 r., ss. 20.

${ }^{8}$ Doroczny obchód imieninowy Józefa Piłsudskiego, program uroczystości, opracowanie graficzne programu J.L. Englert, Ognisko Polskie, Londyn 17 III 1979.
} 


\section{ZYWA LEGENDA \\ DROOA ZYCIA JOZEFA PILSUDSKIEGO \\ W POEZJI I W PIESNI}

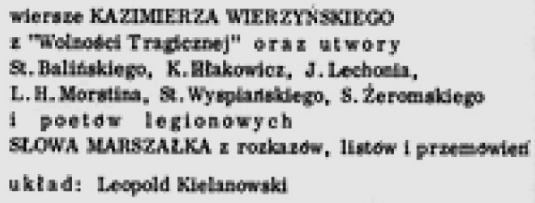

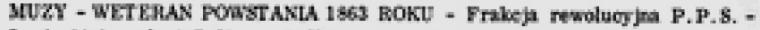

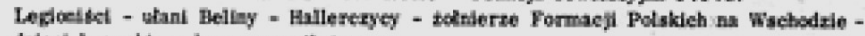
daled lwowsile - harcerze wilensey -

Bow Maracalka exta JOREF OPIBKsid Narrator: EMWARD CHLDZYNSKI

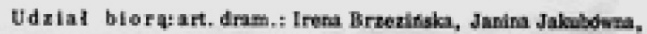

Barbare Retske, Jozef Bzowak, Krzyazod Jalubowlex,

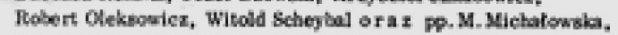

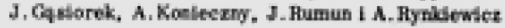

Potąozone Chory Polskie z Londyne Akadeaicki i=. K. Seymatọskiteso, im. F. Chopial, Parafialne pray bodciele \$w. Andraja siboli I przy kodelele Devoela Hd, z. Ealinga i z willesden. SOL WLADYSAW HUCZEK dyf. I kerowik muzyeny RYsZAHD d, NAWHOT

Ze spaty Ludowe! Polska TMCA - Maxury, Syremka, Krakowhk z Amersham, Katolicked MRodriesy a Reading. uklady plastyexe JdzEF WALCzAK

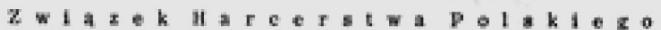

organy: ZOFA COUGHLAX Swiatla: Felikg Sawingi opracowasie bosthumow: H.Minliyask kestiumy max: Z.Soksrika Sentograflai TADEUBz ORLOWLC2 asystent prodzejte J. Brodsd kierowalietwo artystyeano; LEOPOLD KIELAXOWSKI

1. Program obchodów uczczenia setnej rocznicy urodzin Józefa Piłsudskiego, opracowanie graficzne J.L. Englert, Londyn 3 XII 1967 r., s. 9; zbiory własne M. Polaka.

przy organizacji obchodów ${ }^{9}$ Podobnie rok później - 19 III 1983 r. uczczono pamięć Marszałka. Englert podczas organizacji i prowadzenia uroczystości ponownie współpracował z Buchwaldowa ${ }^{10}$. Następnego roku obchody odbyły się $\mathrm{w}$ tym samym miejscu ${ }^{11}$.

${ }_{9}$ Doroczny obchód imieninowy Józefa Piłsudskiego, program uroczystości, opracowanie graficzne programu J.L. Englert, Polski Ośrodek Społeczno-Kulturalny, Londyn 20 III 1982.

${ }_{10}$ Obchód imienin marszałka Piłsudskiego, program uroczystości, opracowanie graficzne programu J.L. Englert, Instytut Józefa Piłsudskiego, Londyn 19 III 1983.

${ }^{11}$ Doroczny obchód dnia imienin Józefa Pitsudskiego, program uroczystości, opieka artystyczna Maryna Buchwaldowa i J.L. Englert, Instytut Józefa Piłsudskiego, Londyn 17 III 1984. Opracowanie graficzne programu oraz układ wieczoru. 


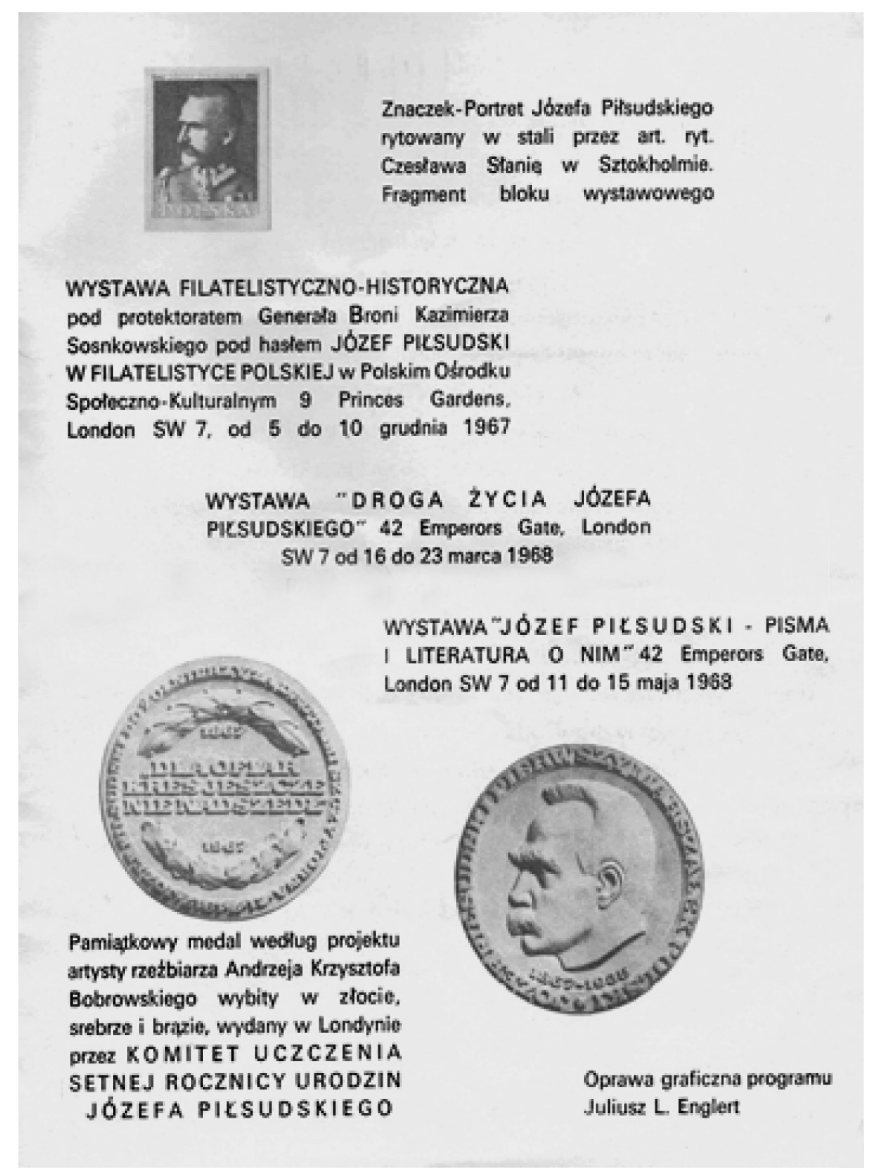

2. Program obchodów uczczenia setnej rocznicy urodzin Józefa Piłsudskiego, opracowanie graficzne J.L. Englert, Londyn 3 XII 1967 r., s. 20; zbiory własne M. Polaka.

W 1985 r. autorem układu wieczoru i oprawy graficznej podobnej rangi uroczystości ponownie był Englert. Słowo wstępne wygłosił Mieczysław Stachiewicz, ówczesny prezes IJP. Z kolei dr Stefan Mękarski zaprezentował referat „Państwo polskie jest wspólnym dobrem wszystkich obywateli”. Podczas części artystycznej wygłaszano słowa i frazy Piłsudskiego, śpiewano pieśni legionowe, wystapił Zespół Męski Zjednoczonych Chórów Polskich w Londynie ${ }^{12}$.

Istotnym obszarem aktywności Englerta było włączenie się w niezwykle ważne dla uchodźstwa polskiego obchody polskiego czynu niepodległościowego. Przygotował m.in. program obchodów jego 60. rocznicy ${ }^{13}$. Uroczystość odbyła

${ }^{12}$ Doroczny obchód święta imienin Józefa Piłsudskiego, opracowanie graficzne programu J.L. Englert, Londyn 16 III 1985.

${ }^{13}$ Legenda wiecznie żywa. Program uroczystości $w$ 60-ta rocznice polskiego czynu zbrojnego, opracowanie graficzne programu J.L. Englert, Great Hall Imperial College, Londyn 18 X 1974. 


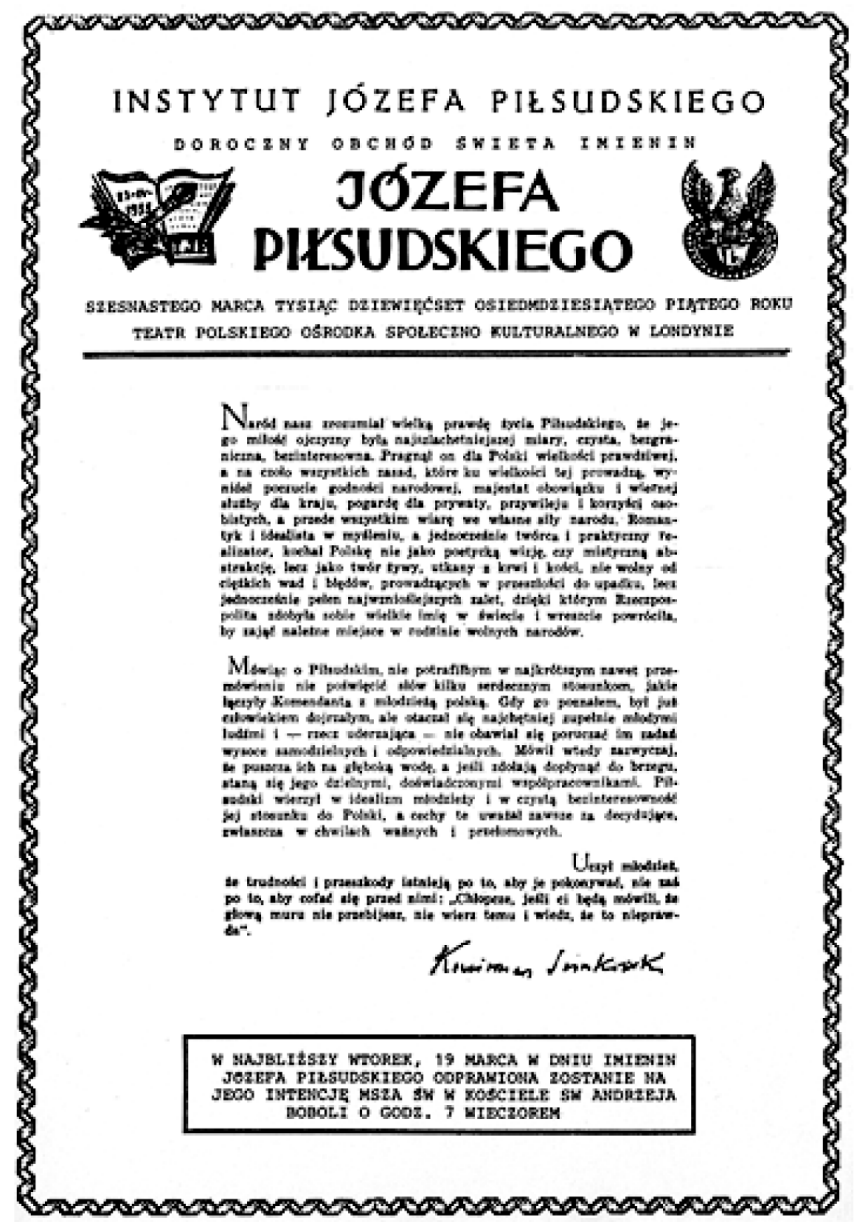

3. Doroczny obchód święta imienin Józefa Piłsudskiego, opracowanie graficzne programu J.L. Englert, Londyn 16 III 1985 r.; zbiory własne M. Polaka.

się w Great Hall Imperial College. W tym samym roku współorganizował i opracował graficznie program obchodów 56. rocznicy odzyskania niepodległości ${ }^{14}$. Podobnie w 1978 r. przygotował pod katem graficznym program 1918-1978. 60. rocznica odzyskania Niepodległości ${ }^{15}$.

W kolejnej dekadzie XX w., w 1980 r., Englert opracował graficznie program obchodów Święta Niepodległości i 60. rocznicy Bitwy Warszawskiej ${ }^{16}$.

14 1918-1974. Wieczór uroczysty, program uroczystości w 56. rocznicę odzyskania niepodległości, opracowanie graficzne programu J.L. Englert, Londyn 1974.

15 1918-1978. 60. rocznica odzyskania Niepodległości, program uroczystości, opracowanie graficzne programu J.L. Englert, Londyn 11 XI 1978.

${ }^{16}$ Uroczysty obchód imienin Józefa Piłsudskiego, opracowanie graficzne programu J.L. Englert, Polski Ośrodek Społeczno-Kulturalny, Londyn XI 1980. 


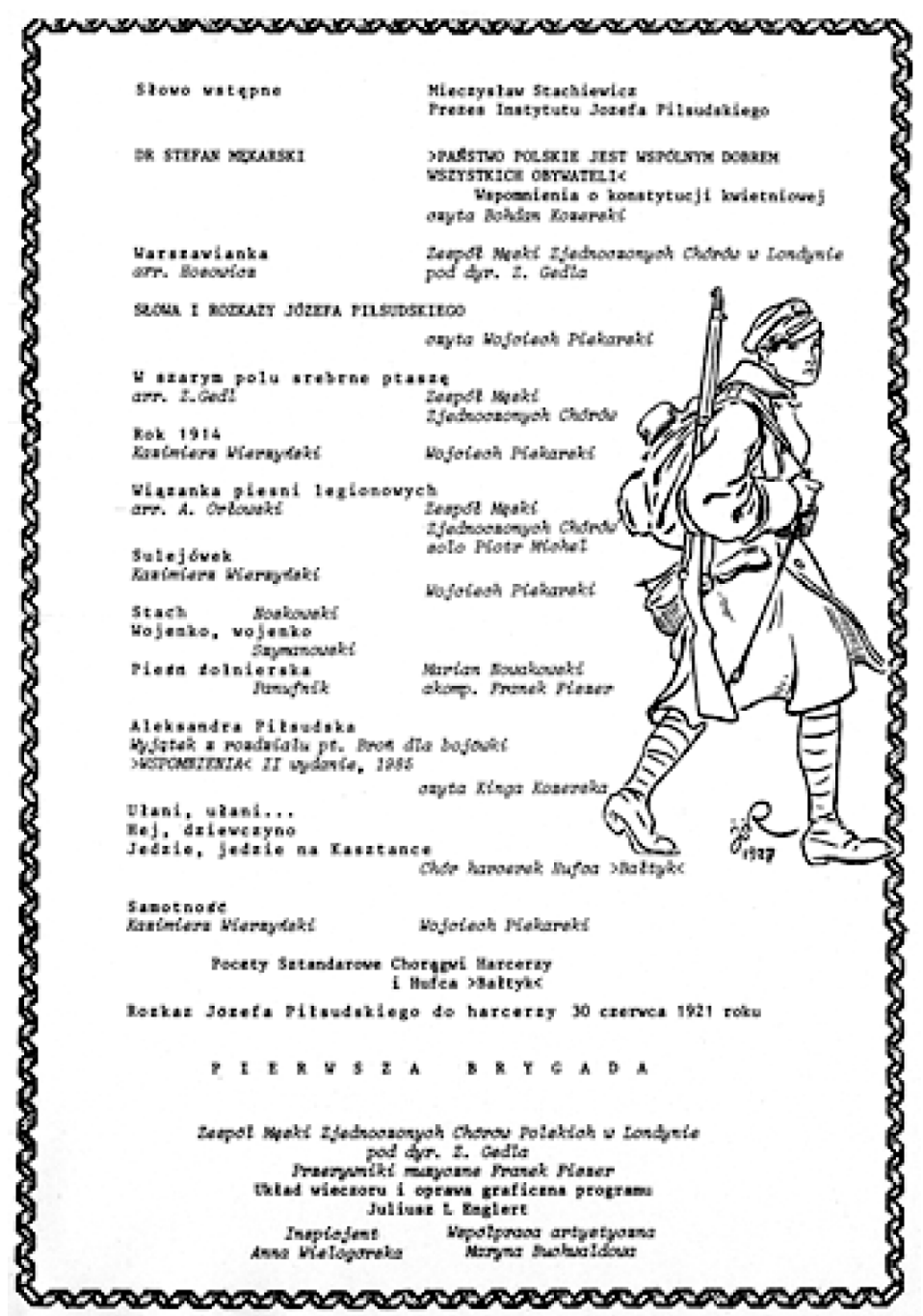

4. Doroczny obchód święta imienin Józefa Piłsudskiego, opracowanie graficzne programu J.L. Englert, Londyn 16 III 1985 r.; zbiory własne M. Polaka.

W 1985 r., oprócz przygotowania wystawy „Józef Piłsudski i jego żołnierze. Wystawa w ramach obchodów 50. rocznicy zgonu Marszałka Polski”, opracował program i katalog wystawy oraz zaproszenia.

W 1988 r. zaangażował się w opracowanie graficzne programu obchodów 70. rocznicy odzyskania niepodległości. Uroczystość odbywała się pod protektoratem prezydenta RP Kazimierza Sabbata, a Komitetowi Wykonawczemu przewodniczył Czesław Zychowicz, prezes Zjednoczenia Polskiego w Wielkiej Brytanii. Englert znalazł się w Komitecie Wykonawczym tego wydarzenia. Obchody uświetniła słowno-muzyczna sztuka Zygmunta Nowakowskiego 


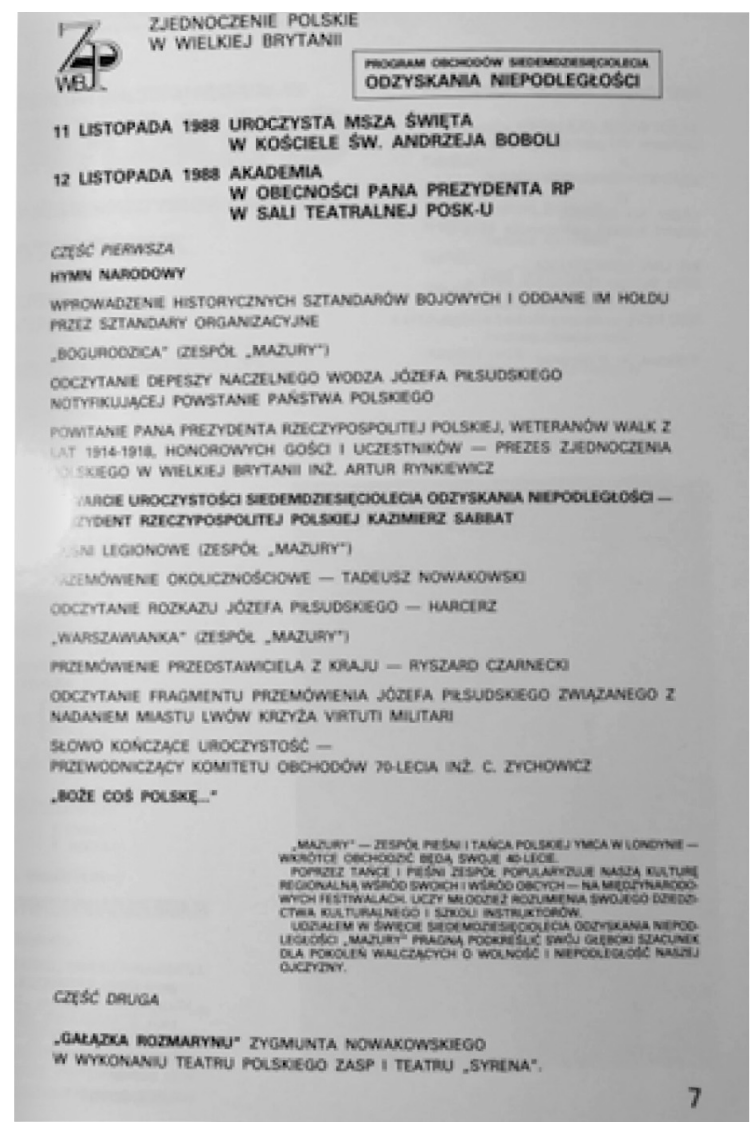

5. Niepodległa - program obchodów 70. rocznicy odzyskania niepodległości, oprawa graficzna J.L. Englert, s. 7; zbiory własne M. Polaka.

Gałazka rozmarynu, również przy współpracy Englerta ${ }^{17}$. Powyżej przedstawiony jest program tychże obchodów.

Dwa lata później, 11 XI 1990 r. Zjednoczenie Polskie w Wielkiej Brytanii przygotowało uroczystość z okazji 72. rocznicy odzyskania niepodległości. O randze wydarzenia świadczyła obecność prezydenta RP Ryszarda Kaczorowskiego, który w orędziu mówił m.in. o przełomie dokonującym się w Kraju i zadaniach Polaków: „W nowych warunkach politycznych musimy przestawić nasz sposób myślenia. Współczesna Polska rzeczywistość wymaga młodych umysłów. Niekoniecznie młodych wiekiem, ale młodszym sposobem myślenia. Zdolnych do otrzaśnięcia się ze smutnych nawyków przeszłości, zdolnych do pozbycia się ponurej tresury totalitaryzmów i ich skutków. Dla

${ }^{17}$ Gałazka Rozmarynu. Stowno-muzyczna sztuka Zygmunta Nowakowskiego o Legionach Józefa Pitsudskiego, opracowanie graficzne programu J.L. Englert, Polski Ośrodek Społeczno-Kulturalny, Londyn 12 XI 1988. 


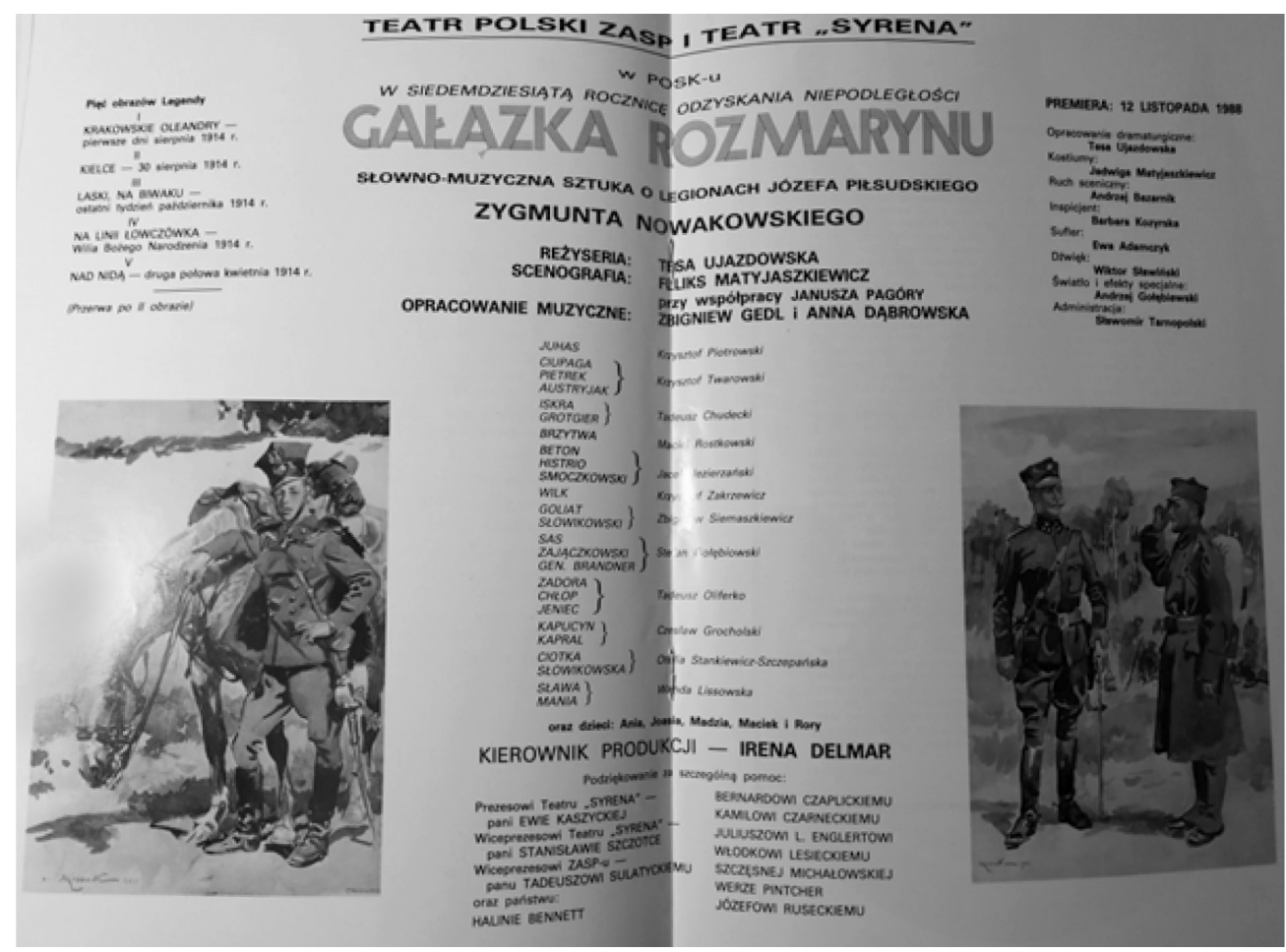

6. Niepodległa - program obchodów 70. rocznicy odzyskania niepodległości, oprawa graficzna J.L. Englert, s. 8-9; zbiory własne M. Polaka.

Polski otwiera się droga do nowej lepszej przyszłości. Starajmy się sprostać nowym zadaniom i uczyńmy naszą Ojczyznę krajem niepodległym i w pełni suwerennym"18. Okolicznościowe przemówienie wygłosił również Zygmunt Szadkowski, przewodniczący Rady Narodowej. Po części oficjalnej goście obejrzeli teatr małych form, realizowany przez Tadeusza Malaka. Englert przygotował program obchodu, w którym wykorzystał wybraną ikonografię z albumu swego współautorstwa o Józefie Piłsudskim. W wydawnictwie znalazły się również kopie czterech pocztowych kart okolicznościowych projektu grafika.

W 1998 r. Englert opracował natomiast graficznie program uroczystego wieczoru z okazji 80. rocznicy odzyskania niepodległości ${ }^{19}$. Organizatorem,

${ }_{18}$ Niepodlegta. Program wieczoru uczczenia 72. Rocznicy Niepodlegtości, opracowanie graficzne programu J.L. Englert, Polski Ośrodek Społeczno-Kulturalny, Londyn 11 XI 1990, s. 1.

${ }_{19}$ Polska Niepodlegta 1918-1998. Program uroczystego wieczoru dla uczczenia 80. Rocznicy odzyskania Niepodległości, opracowanie graficzne programu J.L. Englert, Polski Ośrodek Społeczno-Kulturalny, Londyn 8 XI 1998. W 80. rocznicę odzyskania niepodległości Englert zaprojektował pieczątkę z orzełkiem legionowym i cytatem z wypowiedzi J. Piłsudskiego: „[...] Zwyciężyć i spocząć na laurach to klęska”. A.J.M. Tutak, Polish Postal and Commemorative Service In Great Britain 1941-2003, Londyn 2003, s. 444. 


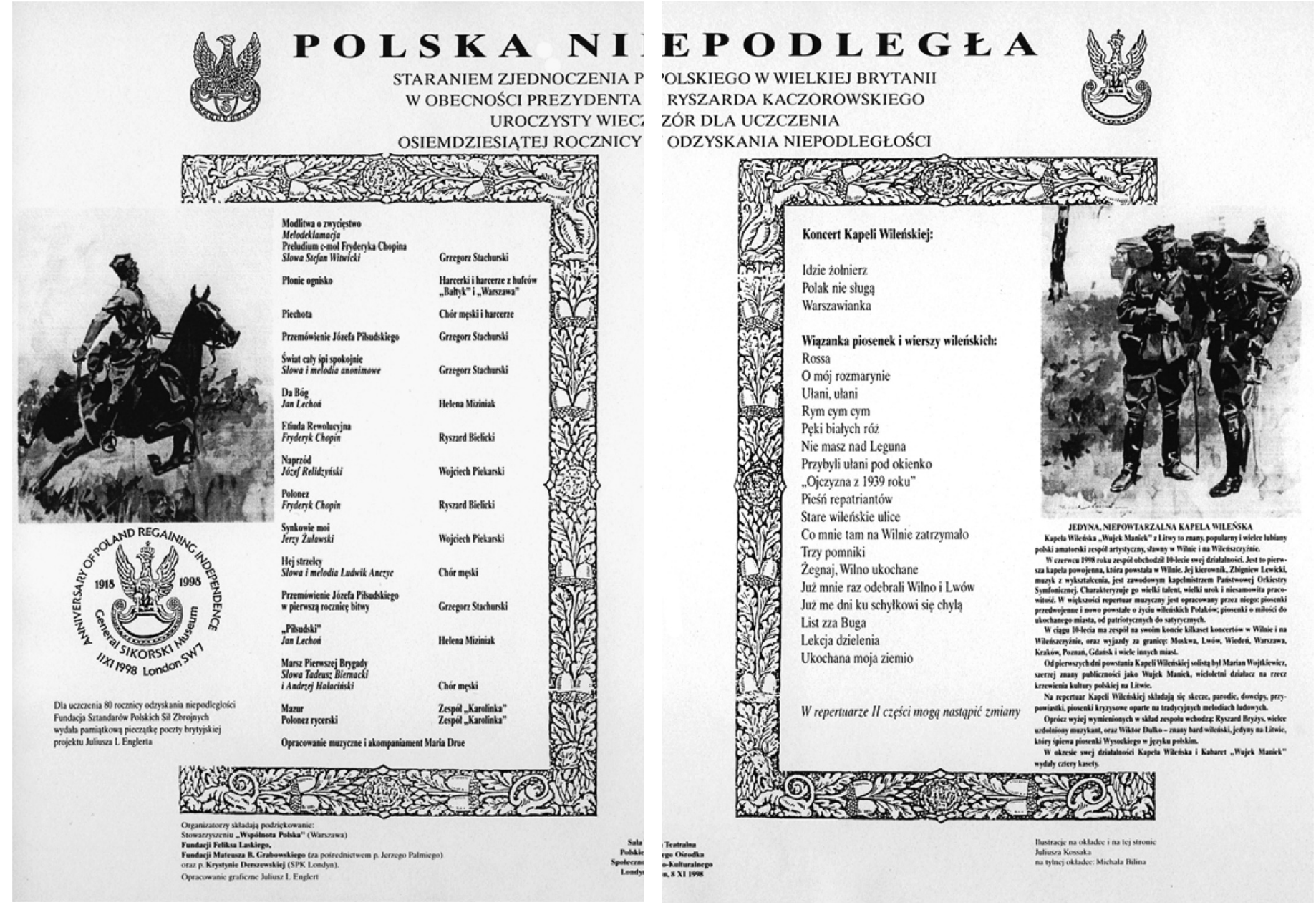

7. Polska Niepodległa - program wieczoru z okazji 80. rocznicy odzyskania niepodległości, opracowanie graficzne programu J.L. Englert, Polski Ośrodek Społeczno-Kulturalny, 8 XI 1998 r.; zbiory własne M. Polaka. 
tak jak w poprzednich przypadkach, było Zjednoczenie Polskie w Wielkiej Brytanii, a uroczystości w POSK uświetnił swą obecnością były prezydent RP na uchodźstwie Ryszard Kaczorowski. Po okolicznościowych przemówieniach widzowie wysłuchali słowno-muzycznego programu patriotycznego, a następnie koncertu Kapeli Wileńskiej, która zaprezentowała piosenki i wiersze wileńskie.

\section{Milenium chrztu Polski}

W 1966 r. Englert aktywnie uczestniczył w organizacji obchodów tysiąclecia chrztu Polski, które emigracja uświetniła 22 maja uroczystością patriotyczna na stadionie White City, przygotowana przez Komitet Tysiąclecia Polski Chrześcijańskiej. Włączył się w graficzne przygotowanie programu uroczystości, m.in. wykonując okładkę. Warto zwrócić uwagę na nadzwyczajny i niezwykle bogaty charakter polskiego święta. Na stadionie zgromadziło się ok. 40 tys. Polaków. Mszę św. celebrowali ks. bp Władysław Rubin oraz kard. John Carmel Heenan, arcybiskup Westminsteru. Nabożeństwo miało charakter ekumeniczny w związku z udziałem duszpasterzy Polskiego Kościoła Prawosławnego, Polskiego Kościoła Ewangelickiego oraz przedstawicieli Brytyjskiej Rady Kościołów. Obecne były na niej poczty sztandarowe Polskich Sił Zbrojnych. Po mszy rozpoczęło się widowisko milenijne „Litania polskich dziejów”, składające się z czterech części: I - Tarcze polskich miast, II - Nasze tysiąclecie (widowisko historyczne), III - Róża polskich miast (przegląd tańców narodowych), IV - Wkraczamy w nowe tysiąclecie (m.in. uroczyste ślubowanie). Układ widowiska opracował i wyreżyserował je Leopold Kielanowski ${ }^{20}$.

\section{Rocznice wybuchu II wojny światowej i napaści sowieckiej na Polskę}

Englert włączał się również w upamiętnianie rocznic wybuchu II wojny światowej. W 1969 r. opracował graficznie program uroczystego obchodu 30. rocznicy kampanii wrześniowej 1939 r. oraz 25. rocznicy działań wojennych na Zachodzie i Powstania Warszawskiego. Uroczystość odbyła się w Royal Albert Hall ${ }^{21}$.

${ }^{20}$ Zob. Tysiaclecie Polski Chrześcijańskiej, wyd. Komitet Tysiąclecia Polski Chrześcijańskiej, Londyn 22 V 1966, ss. 35.

${ }^{21}$ Na polu chwaty 1939-1945, program uroczystego obchodu XXX rocznicy Kampanii Wrześniowej 1939 r. i XXV rocznicy działań wojennych na Zachodzie i Powstania Warszawskiego, opracowanie graficzne programu J.L. Englert, Royal Albert Hall, Londyn 1969. 
8. Tysiąclecie Polski Chrześcijańskiej, wyd. Komitet Tysiąclecia Polski Chrześcijańskiej, Londyn $22 \mathrm{~V}$ 1966 r., pierwsza strona okładki; zbiory własne M. Polaka.

9. Tysiąclecie Polski Chrześcijańskiej, wyd. Komitet Tysiąclecia Polski Chrześcijańskiej, Londyn $22 \mathrm{~V}$ 1966 r., s. 32-33; zbiory własne M. Polaka.
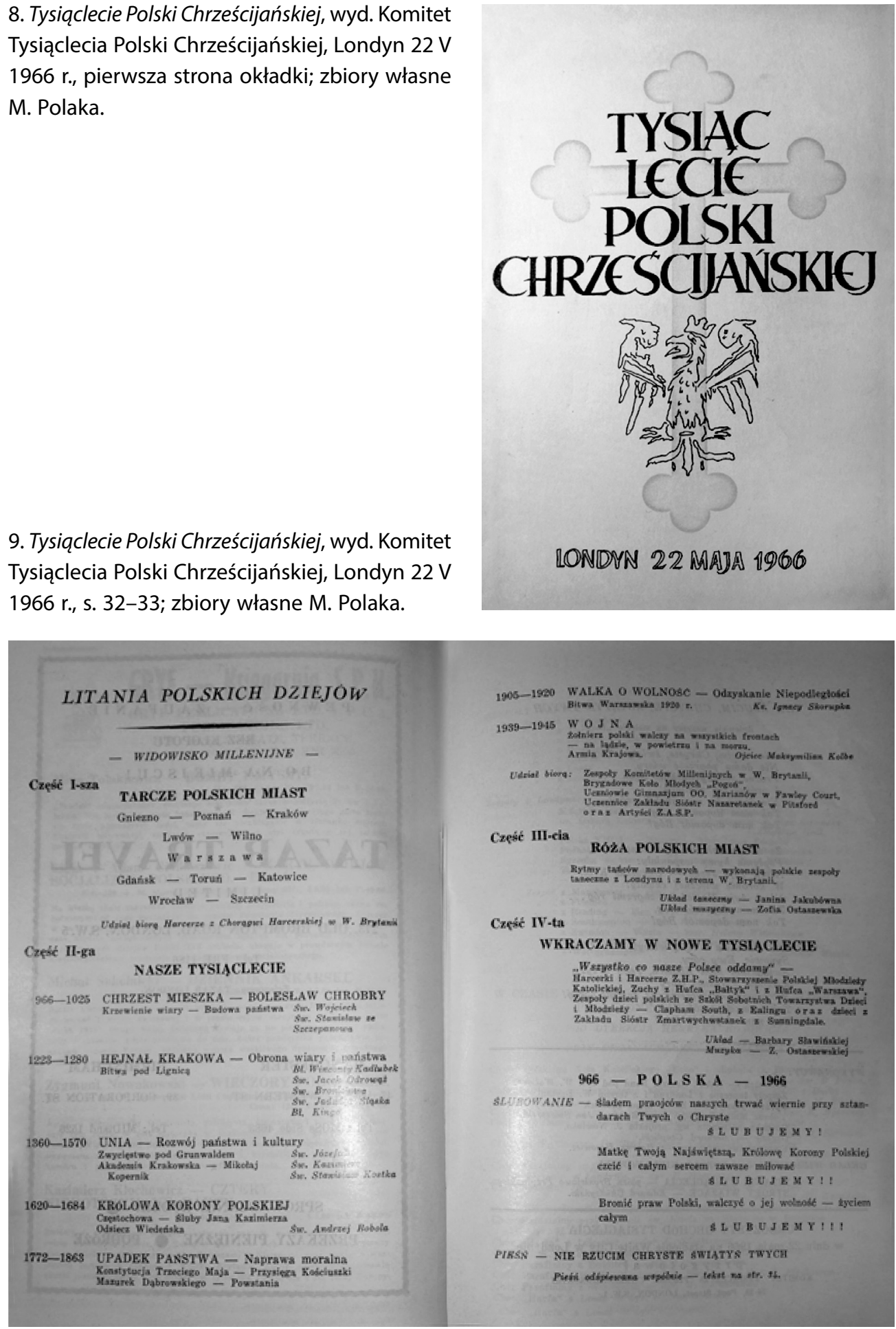


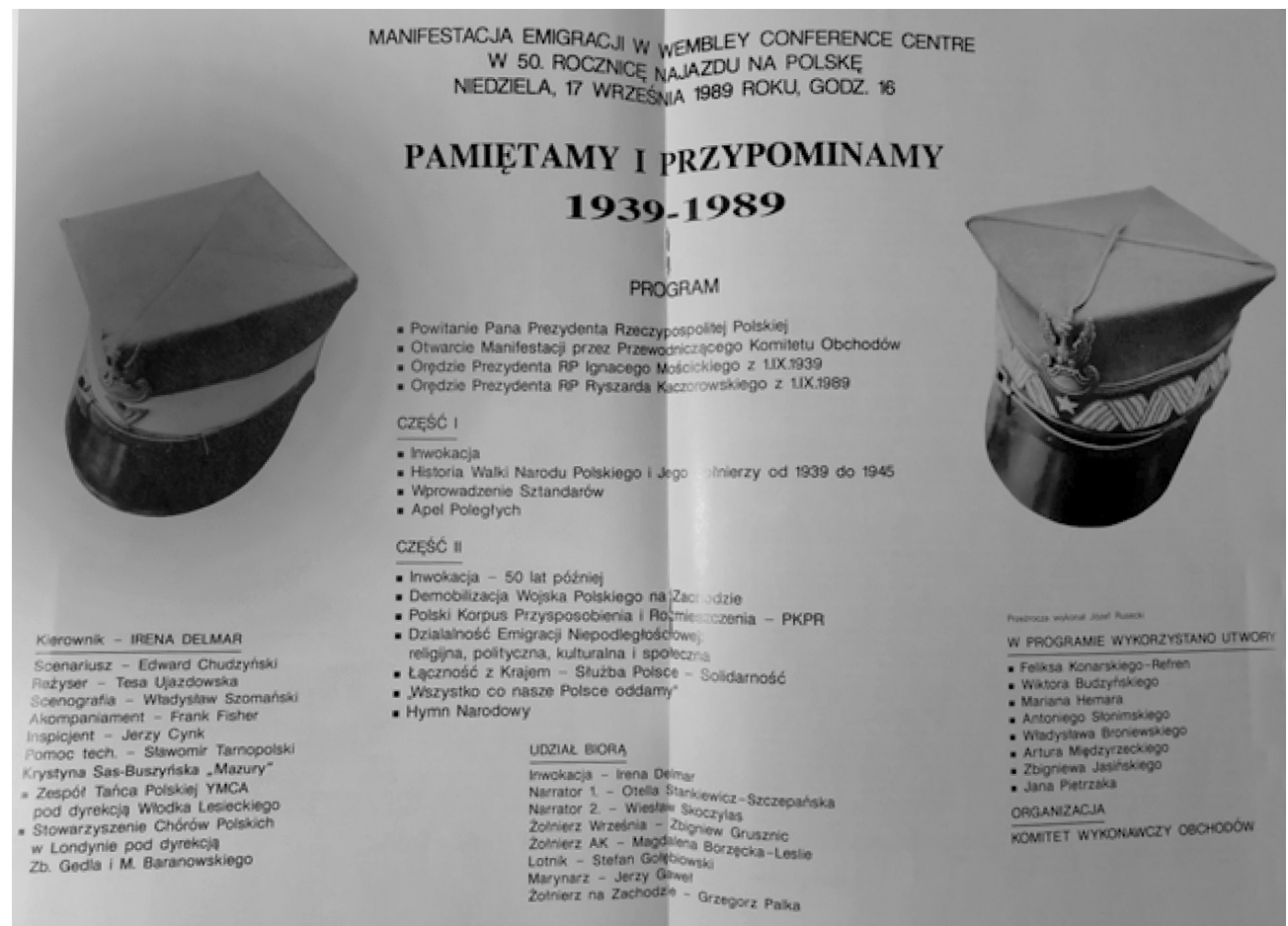

10. Pamiętamy i przypominamy 1939-1989, wydawnictwo w 50. rocznicę najazdu na Polskę wraz z programem manifestacji, opracowanie graficzne programu J.L. Englert, Londyn 1989; zbiory własne M. Polaka.

W 1989 r. opracował graficznie publikację wydana w 50. rocznicę najazdu na Polskę $e^{22}$. Obchody odbyły się pod honorowym protektoratem prezydenta RP Ryszarda Kaczorowskiego. Englert w Komitecie Wykonawczym, wraz z Irena Delmar i Włodzimierzem Lesieckim, odpowiadał za program artystyczny wieczoru. Orędzie z okazji rocznicy wystosował prezydent Kaczorowski. Publikacja okolicznościowa składała się z dwóch części. W pierwszej umieszczono teksty historyczne, w tym wybrane przemówienia polskich prezydentów i innych czołowych polityków z lat 1939-1945, obrazujące najbardziej dramatyczne dla polskiego narodu momenty. Druga część poświęcona została aktualnym przemowom okolicznościowym. Centralną część publikacji stanowił program manifestacji emigracji w Wembley Conference Centre w 50. rocznicę najazdu na Polskę. Znamienny jest wykaz głównych obchodów Roku Polskiego, znajdujący się na ostatniej stronie. Na uroczystości rocznicowe z okazji 50-lecia najazdu na Polskę złożyło się 19 inicjatyw ${ }^{23}$, m.in.: Festiwal Młodzieży Polskiej

22 Pamiętamy i przypominamy 1939-1989, wydawnictwo w 50. rocznicę najazdu na Polskę wraz z programem manifestacji, opracowanie graficzne programu J.L. Englert, Londyn 1989.

${ }^{23}$ Ibidem. 
YMCA, 5. Zlot Związku Harcerstwa Polskiego w USA, obchody 10-lecia pontyfikatu Ojca Świętego, 70-lecia odzyskania niepodległości, Konferencja Muzeów, Archiwów i Bibliotek Polskich na Zachodzie, Zjazd Rady Polonii Wolnego Świata, uroczystość pod pomnikiem katyńskim i inne.

\section{Rocznica katastrofy gibraltarskiej}

Rok 1973 stał się okazja do oddania hołdu gen. Władysławowi Sikorskiemu w 30. rocznicę katastrofy lotniczej na Gibraltarze, w której zginął wraz z 16 osobami, w tym gen. Tadeuszem Klimeckim - szefem sztabu Naczelnego Wodza oraz swoją córka - por. Zofią Leśniowska. Na obchody rocznicy katastrofy Englert opracował pamiątkowe wydawnictwo, w którym zamieszczone zostały materiały biograficzne dotyczace gen. W. Sikorskiego, w tym bogata ikonografia. Obchody przygotował komitet złożony z delegatów organizacji zgrupowanych w Zjednoczeniu Polskim w Wielkiej Brytanii. W prezydium komitetu zasiedli: ambasador Edward Raczyński, ks. bp Władysław Rubin, gen. Stanisław Kopański, gen. Marian Kukiel oraz Alfred Urbański ${ }^{24}$. Uroczystość uczczenia pamięci gen. Sikorskiego objęta została protektoratem prezydenta RP Stanisława Ostrowskiego. 1 VII 1973 r. hołd Naczelnemu Wodzowi złożono na cmentarzu w Newark. 3 lipca ambasador Raczyński otworzył w Instytucie Polskim i Muzeum im. gen. Sikorskiego wystawę poświęconą pamięci premiera, a 4 lipca odbyła się uroczysta msza św. w kościele polskim przy Devonia Road, po której odsłonięto tablicę pamiątkowa ${ }^{25}$. Kulminacją obchodów była wieczornica „Świadkowie historii”. Akademia ku czci gen. Sikorskiego, przywódcy walczącego narodu, odbyła się w Great Concert Hall w Londynie. Wzięli w niej udział najważniejsi ówcześni przywódcy uchodźstwa polskiego w Wielkiej Brytanii.

Swoista puentą patriotycznej drogi gen. Sikorskiego było przewiezienie jego prochów do Kraju w dniach 13-17 IX 1993 r. ${ }^{26}$ Na tę okoliczność Englert opracował bogato ilustrowane wydawnictwo upamiętniające działalność Naczelnego Wodza. Na ostatniej stronie zamieścił oficjalną korespondencję między prezydentem Lechem Wałęsą i premierem rządu brytyjskiego Johnem Majorem na temat przetransportowania ciała Sikorskiego do Polski27.

${ }^{24}$ W XXX-ta rocznice katastrofy $w$ Gibraltarze 1943, pamiątkowe wydawnictwo oraz program obchodów 30. rocznicy śmierci gen. Władysława Sikorskiego, opracowanie graficzne programu J.L. Englert, Zjednoczenie Polskie w Wielkiej Brytanii, Londyn 1-6 VII 1973, s. 5.

25 Ibidem, s. 13.

${ }^{26}$ Szczegółowo na temat wcześniejszych inicjatyw przeniesienia szczątków gen. Sikorskiego do Polski zob. K. Tarka, Rozgrywka nad trumna. Sprowadzenie prochów generała Wtadystawa Sikorskiego do Polski, „Dzieje Najnowsze” 2010, nr 3, s. 55-80.

${ }^{27}$ Generat Wtadystaw Sikorski 1881-1943, oprac. J.L. Englert, Newark 1993. 


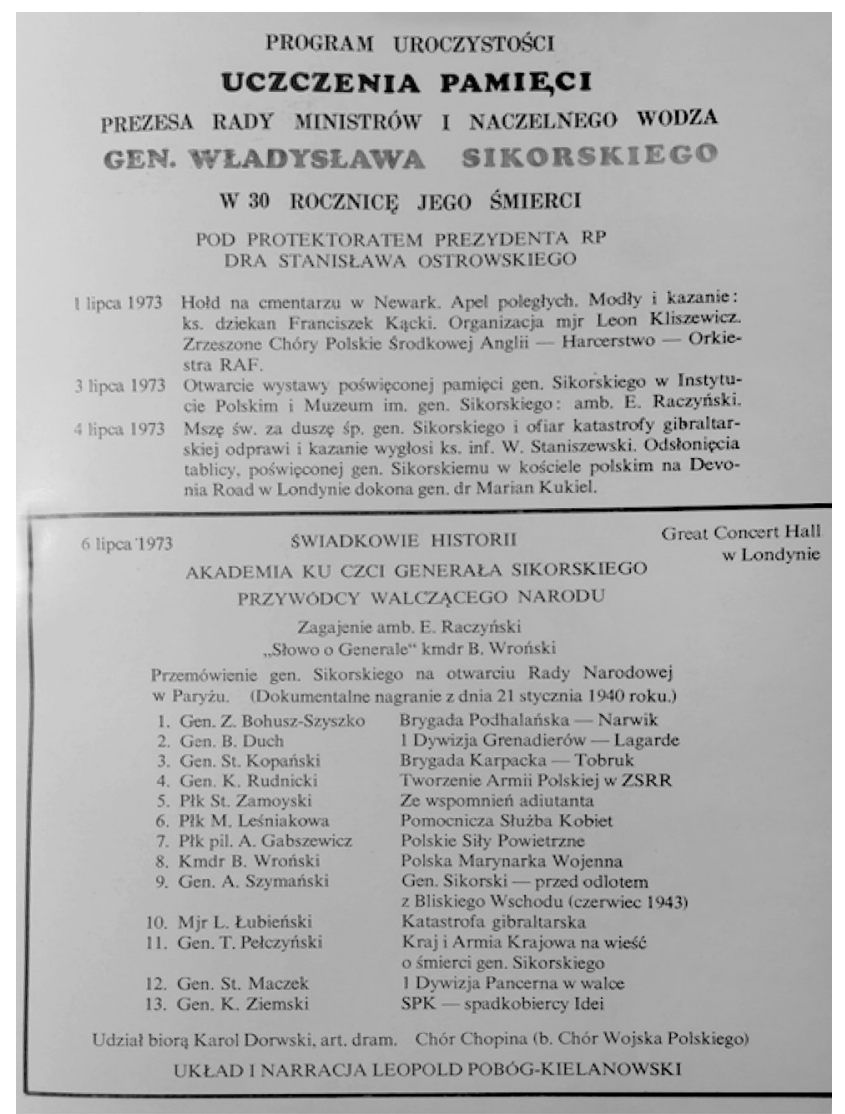

11. WXXX-ta rocznicę katastrofy w Gibraltarze 1943, pamiątkowe wydawnictwo oraz program obchodów 30. rocznicy śmierci gen. Władysława Sikorskiego, opracowanie graficzne programu J.L. Englert, Zjednoczenie Polskie w Wielkiej Brytanii, Londyn 1-6 VII 1973 r., s. 13; zbiory własne M. Polaka.

$* * *$

Major Juliusz Ludwik Englert dobrze zasłużył się Ojczyźnie, jej historii, pamięci o bohaterach, zwłaszcza Marszałku Józefie Piłsudskim, gen. Władysławie Sikorskim czy gen. Władysławie Andersie. Wraz z jego odejściem zabrakło tak wybitnego kronikarza, zamknęła się nieubłaganie niezwykła karta polskiej obecności w Wielkiej Brytanii. Analiza ogromnej liczby materiałów okolicznościowych, artykułów prasowych, publikacji albumowych, wystaw fotografii, kart i stempli filatelistycznych stanowi nieomal niewyczerpalne źródło wiedzy o polskim uchodźstwie w Wielkiej Brytanii, o Polakach kultywujacych najlepsze polskie cechy narodowe, krzepiących się bohaterskimi kartami historii, ale również potrafiących zadumać się nad trudną sytuacja ciemiężonej Polski powojennej. Uroczystości te miały istotne znaczenie dla 
wzmocnienia i konsolidacji uchodźstwa polskiego. Dzięki temu Polacy na obczyźnie mogli przez dekady realizować misję wspierania Polaków w Kraju w ich staraniach o odzyskanie niepodległości i wytrwać w tym działaniu do momentu uzyskania przez Ojczyznę suwerenności.

\section{Streszczenie}

Godne obchodzenie rocznic i jubileuszy przez uchodźstwo polskie w Wielkiej Brytanii było możliwe nie tylko dzięki zaangażowaniu władz polskich na obczyźnie, ale również wydatnemu włączeniu się społeczności polskiej na czele z wybitnymi społecznikami, którzy nie szczędzili talentów, sił i środków dla upamiętnienia ważnych w odczuciu Polaków wydarzeń z historii Polski. Celem niniejszego artykułu jest przedstawienie wyników analiz prac Juliusza L. Englerta jako kronikarza emigracji, grafika i współautora programów obchodów rocznic narodowych. Podstawę źródłową tych rozważań stanowi szeroki dorobek publikacyjny Englerta, dostępny niestety głównie w archiwach i bibliotekach polskich w Wielkiej Brytanii, jak również znajdujący się w zbiorach autora niniejszego artykułu. Prace Englerta są doskonałym materiałem poglądowym na temat genezy, okoliczności i przebiegu obchodów ważnych dla polskiego uchodźstwa wydarzeń z historii Polski. Analiza prac Englerta pozwala stwierdzić nadzwyczajne znaczenie tych uroczystości dla wzmocnienia i konsolidacji uchodźstwa polskiego. Dzięki temu Polacy na obczyźnie mogli przez dekady realizować misję wspierania Polaków w Kraju w ich staraniach o uzyskanie suwerenności.

\section{Celebrations of National Anniversaries by Polish Political Emigration in Great Britain in the Light of Occasional Prints of Juliusz L. Englert}

A solemn celebration of anniversaries and jubilees of great historical events by Polish emigration in Great Britain was possible not only due to the involvement of the Polish authorities in exile, but also thanks to the considerable participation of the Polish community, including outstanding social activists who did not spare their talent, strength and resources to commemorate important events from the history of Poland.

The purpose of this article is to present the results of research on the work of Juliusz L. Englert as chronicler of the emigration, graphic artist and co-author of the programmes of celebrating national anniversaries. The study is based on Englert's extensive publishing output, unfortunately available mainly in Polish archives and libraries in Great Britain, but also in the possession of the author of this text.

Englert's works are excellent demonstrative material for a thorough study of the genesis, circumstances and course of the celebrations of events from Polish history important for the Polish people in exile. An analysis of Englert's works reveals the extraordinary importance of these ceremonies for strengthening and consolidating of Polish people in exile. Over decades they made it possible for Poles abroad to carry out the mission of supporting their fellow countrymen in Poland in their efforts to regain sovereignty.

\section{Bibliografia}

Bednarek L., Mrugała W., Juliusz Ludwik Englert - żotnierz, fotograf, filatelista - historia o wyjatkowym człowieku, w: Katalog Krajowej Wystawy Filatelistycznej „Żotnierz polski podczas II wojny światowej”, red. T. Galant, Koszalin 2015, s. 65-72. 
Danel J.K., Druga Wielka Emigracja 1945-1990. Stownik biograficzny, t. I, Zamość 2011. Generat Wtadystaw Sikorski 1881-1943, oprac. J.L. Englert, Newark 1993.

Grodziska K., Polskie groby na cmentarzach Londynu, Kraków 1995.

Ojczyzna w obiektywie. Imponderabilia kronikarza Juliusza L. Englerta na emigracji, red.

A. Biernat, W. Stępniak, Warszawa 2010.

Polak M., Juliusza Englerta pamięć o Marszałku, w: Marszałek Józef Piłsudski w pamięci Polaków, red. nauk. P. Michalak, B. Polak, M. Polak, W. Wierzejewski, Koszalin 2016, s. $169-185$.

Rostocki W., „Stepañ” w Londynie, w: Ojczyzna w obiektywie. Imponderabilia kronikarza Juliusza L. Englerta na emigracji, red. A. Biernat, W. Stępniak, Warszawa 2010, s. 15-16.

Suchcitz A., Pptk Adam Englert, w: Ojczyzna w obiektywie. Imponderabilia kronikarza Juliusza L. Englerta na emigracji, red. A. Biernat, W. Stępniak, Warszawa 2010, s. 19-21.

Tarka K., Rozgrywka nad trumna. Sprowadzenie prochów generała Wtadystawa Sikorskiego do Polski, „Dzieje Najnowsze” 2010, nr 3, s. 55-80.

Tutak A.J.M., Polish Postal and Commemorative Service In Great Britain 1941-2003, Londyn 2003.

Biog r a m: Michał Polak - dr hab. nauk humanistycznych, prof. nadzw. Politechniki Koszalińskiej; dziekan Wydziału Humanistycznego. Autor ponad 130 publikacji, w tym kilkunastu monografii autorskich i współautorskich oraz wyborów źródeł. Jego badania koncentrują się na historii najnowszej Polski, w szczególności na międzynarodowych, gospodarczych i biograficznych aspektach powstania wielkopolskiego i Wojska Wielkopolskiego, historii II wojny światowej, emigracyjnej myśli politycznej i ekonomicznej oraz na polityczno-gospodarczej problematyce współczesnej Europy. E-mail: mcpol@o2.pl. 